\title{
THE INFLUENCE OF E-SERVICESCAPE ON MOBILE SHOPPING INTENTION: THE MEDIATING ROLE OF CUSTOMER SATISFACTION
}

\author{
Amy Chu May YEO ${ }^{1 *}$ \\ Xiu Lei $\mathrm{MOH}^{2}$ \\ Boon Tiong LOW ${ }^{3}$
}

\begin{abstract}
Received: June 2021 | Accepted: July 2021 | Published: August 2021
Please cite this paper as: Yeo, A.C.M., MOH, X.L., Low, B.T. (2021) The influence of e-servicescape on mobile shopping intention: the mediating role of customer satisfaction, Holistica Journal of Business and Public Administration, Vol. 12, Iss. 2, pp.64-92
\end{abstract}

\begin{abstract}
This paper aims to investigate, through aesthetic appeal, layout and functionality, interactivity and financial security, the impact of generation $X$ perceptions of the e-servicescape in mobile shopping on perceived value and customer satisfaction following the sequence of the $S-O-R$ framework. $A$ survey involved 231 generation $X$ respondents who shopped using mobile apps at least one mobile purchase in the past six months. The collected data were analysed using Structural Equation Modelling (SEM), Partial Least Square (PLS). The results revealed that aesthetic appeal, layout and functionality and interactivity could influence the perceived value and would lead to the mobile shopping intention, whilst customer satisfaction could impact the perceive value and mobile shopping intention through the mediating process. This research provides insight into the new effects of each dimension of e-servicescape on perceived value, customer satisfaction and the mobile purchase intention, thus improving the existing knowledge in the field of servicescape and mobile shopping customer behaviour.
\end{abstract}

Keywords: E-servicescape; Generation X; Customer satisfaction; Perceived value; Mobile purchase intention

\section{Introduction}

Technological advances have developed new platforms for services and goods that provide various benefits to organizations who are keen to promote and sell their services. Therefore, it will influence the number of internet users to grow significantly, which will

\footnotetext{
${ }^{1}$ Associate Professor, Tunku Abdul Rahman University College, Jalan Genting Klang, Setapak, 5330 Kuala Lumpur, Malaysia, yeocm@tarc.edu.my.

* Corresponding author.

${ }^{2}$ Executive, Fovty Tech Sdn Bhd, Kuala Lumpur, Malaysia, Little_leilei@hotmail.com.

3 Programme Leader, Tunku Abdul Rahman University College, Jalan Genting Klang, Setapak, 5330 Kuala Lumpur, Malaysia, lowbt@tarc.edu.my.
} 
affect the rise of electronic commerce (e-commerce) and mobile shopping ( $m$-shopping). The development of e-commerce and $\mathrm{m}$-commerce has enabled people to buy anything at any time, which has opening new opportunities for customers. They are also enabled to compare product characteristics and prices easily, hence making it the most flexible and convenient way of purchasing (Tankovic and Benazic 2018).

Tankovic and Benazic (2018) defined e-commerce as a process which includes a user using the internet to explore products and services to meet their demands. This evolution with the purpose of satisfying the requirements of people throughout their life (Wu and Wang 2005; Lu and Su 2009). It is no surprise that consumer understanding, and satisfaction play a key role in creating long-term customer relationships (Lien, Wen, and Wu 2011). Therefore, to increase customer satisfaction, the design of the platform is important. Hence, mobile commerce needs to know about how the generation $X$ perception toward the creation of a mobile shopping platform is and hence the E-servicescape are included in this study. According to Statista (2018), retail e-commerce revenues exceeded \$2 trillion in the year 2017 , an increase of $23 \%$ over the past year. The forecast in the year 2021 of mobile e-commerce could make up almost three-quarters (72\%) of e-commerce revenues in some $\$ 3.5$ trillion (Statista 2018).

Despite the rapid and extensively developed mobile technologies and apps formshopping, hence, understanding consumer views and acceptance of $\mathrm{m}$-shopping is crucial. Therefore, a number of researchers and practitioners in the marketing area have focused mainly on characteristics of e-commerce and customer purchasing intention to predict the likelihood of technology adoption (Wu and Wang 2005; Kim, Chan, and Gupta 2007). Moreover, previous studies have shown the relationship between the e-servicescape and e-satisfaction (Szymanski and Hise 2000; Ballantine 2005), trust (Papadopoulou et al. 2001) later purchase behaviour (Menon and Kahn 2002), pleasure (Eroglu, Machleit, and Davis 2003), trust and purchase intention (Harris and Goode 2010), and trust and word of mouth (WOM) (Tran and Strutton 2016). Nevertheless, understanding of electronic servicescape (e-servicescape) on mobile shopping remains murky, due to the limited empirical evidence that has been obtained and examined. Most of the research of the eservicescape is focused on e-commerce rather than the $\mathrm{m}$-commerce. Although $\mathrm{m}$ commerce is a new channel of conducting commerce, it is not the same as e-commerce (Cao et al. 2014). One of the research gaps for this research is the e-servicescape on $\mathrm{m}$ commerce that will affect the mobile shopping intention.

\section{Literature Review}

\subsection{Linking e-servicescape to customers' perceived value}

The servicescape is one of the concepts that consumers associate with every value proposition, thereby affecting the perceptions of their service in the physical shopping environment (Nilsson and Ballantyne 2014). Thus, the servicescape experience generates value by increasing customer satisfaction (Voss, Roth, and Chase 2008). Hence, the 
servicescape concept can be adapted to mobile shopping to support customer perceived value. It is important to investigate the relation between e-servicescape dimension and perceived value to predict the process for generating utility perception from four elements of e-servicescape. According to Tankovic and Benazic (2018), there are two eservicescape dimensions are positively correlated to perceived value while one of them is rejected. There are several influential commentators agree that mobile app design functionality is important for reflective user assessments and behaviours (Harris and Goode 2010). Moreover, internet research shows that user perceptions are closely related to the website's navigability and usability (Evans and King 1999; Hoque and Lohse 1999). Indeed, research of internet users concludes that customising and individualising websites are central to customer assessments (Menon and Kahn 2002).

In addition, there are many studies show that interactivity is positively linked to the perceived benefits (Coyle and Thorson 2001; Liu and Shrum 2002; Sundar and Kim 2005). Through providing customers with the fun and experience flow, the research states that interactivity will increase the value (Hoffman and Novak 1996; Sicilia, Ruiz, and Munuera 2005). Furthermore, in connection with the relationship between service quality and perceived value for the consumer in traditional and online shopping, most of the empirical studies showed that service quality is positively related to perceived value (Bauer, Falk, and Hammerschmidt 2006; Brady, Robertson, and Cronin 2001; Cronin, Brady, and Hult 2000; Kuo, Wu, and Deng 2009). Therefore, this study predicts that the perception of the e-servicescape has a positive linkage to perceived value.

Based on the discussion above, the following hypotheses are proposed:

$\mathrm{H} 1$ : There is a positive relationship between aesthetic appeal and perceived value.

$\mathrm{H} 2$ : Layout functionality is positively associated with the perceived value.

H3: Interactivity has a positive relationship with the perceived value.

H4: Financial security is positively related to the perceived value.

\subsection{Linking perceived value to customer satisfaction}

Zeithaml (1988) noted that perceived value is the customer's overall assessment of the utility of the product, which is based on the perception of what is received and given. Therefore, customer satisfaction is directly linked with the perceived value; the perceived value will increase when customer satisfaction also increases (Koupai, Alipourdarvish, and Sardar 2015). According to Bolton and Drew (1991), consumers' perception of value is affected by monetary costs, non-monetary costs, customer tastes and customer characteristics. There are several researcher empirical studies shows the perceived value has an important and heavy effect on customer satisfaction (Patterson and Spreng 1997; Lai 2004; Lee et al. 2005; Lien, Wen, and Wu 2011). Thaler Richard (1985) proposed in the transaction utility theory suggested that the perceived value positively affects the customers' willingness to purchase. While Dodds, Monroe, and Grewal (1991) and Grewal, Monroe, and Krishnan (1998) noted that upon developing a perceived value, 
customers grow willingness to purchase. Therefore, this study predicts that the perceived value has significant relationship on customer satisfaction.

H5a: Customer perceived value is positively related to customer satisfaction.

\subsection{Customer satisfaction on mobile shopping intention}

According to Zeithaml, Berry, and Parasuraman (1996), the more satisfied the users are, the more willing they are to buy through social commerce sites. Satisfaction is playing a very important role in affecting the users' purchase intention based on prior studies (Zeithaml, Berry, and Parasuraman 1996; Gan and Wang 2017). Satisfaction significantly influences users' willingness to buy mobile value-added services (Kuo, Wu, and Deng 2009). Moreover, Hsu and Lin (2016) revealed that the satisfaction of real users has a significant impact on their willingness to buy on the mobile app. Zhang et al. (2015) concluded that satisfaction significantly impacts consumer intention. If the use of social commerce sites could encourage users to become satisfied with the sites, the purchasing intent of users will be strengthened through the sites. Therefore, the following hypothesis is predicted the customer satisfaction has a significant relationship on mobile shopping intention.

$\mathrm{H} 5 \mathrm{~b}$ : When customers are satisfied, it is positively related to mobile shopping intention.

\subsection{Customers' perceived value and mobile shopping intention}

There are some researchers have identified the perceived value is positively correlated to purchase intention (Parasuraman and Grewal 2000; Dodds, Monroe, and Grewal 1991). To increase perceived value, the customer will likely switch from the company that provided low perceived value to direct competing business. Hence, the loyal customer of the company will decrease (Chang, Wang, and Yang 2009). Even happy consumers are unlikely to buy again on the same platform unless they believe they are getting the best value. On the contrary, the customer will continue to search for other websites to find better value (Kanji 2002; Anderson and Srinivasan 2003). In addition, Lin and Wang (2006) studied shows that perceived value had a significant relationship on customer satisfaction and mobile commerce repurchase intention. Similarly, the conceptual model of factors leading to the post-purchase purpose of mobile value-services has been identified and evaluated by Kuo, Wu, and Deng (2009). Their results indicate that perceived value influences both consumer satisfaction and post-purchase intention. Apparently, when using mobile apps and services, customers will build this value perception. Past studies have also shown that perceived value affects consumer satisfaction and behavioural intent (Yang and Peterson 2004; Li, Li, and Kambele 2012; Hsu and Lin 2015; Cronin, Brady, and Hult 2000; Brady and Robertson 1999). Other than that, Ko, Kim, and Lee (2009) research show their perceived value are playing an important role in deciding the behavioural intention which based on the technology adoption in mobile shopping which is based on Korean perspectives. Therefore, this study predicts that the perceived value has significant relationship on mobile shopping intention:

H5c: Customers' perceived value is positively associated with mobile shopping intention. 


\subsection{Mediating Effect of Customer Satisfaction}

Regarding the indirect path, this study indicated a mediating role of customer satisfaction between perceived value and mobile shopping intentions, which are consistent with some prior studies (Cronin, Brady, and Hult 2000; Hu and Kandampully 2009; Patterson and Spreng 1997; Tam 2004). However, the hypothesis of this study is opposite to Chang, Wang, and Yang (2009) study. According to Chang, Wang, and Yang (2009), if satisfied customers feel that their money is not getting the best value, they are less likely to patronize e-commerce. Lastly, although our research supports the mediating role of customer satisfaction on the relationship between perceived value and mobile shopping intention, which is consistent with Cronin, Brady, and Hult (2000) study and is opposite to Chang, Wang, and Yang (2009) study: the indirect effect of perceived value on mobile shopping intention through customer satisfaction is not significant in Taiwan. As customer satisfaction acts as a mediator between perceived value and mobile shopping intention varies among industries and countries. According to Edward and Sahadev (2011), the theoretical framework hierarchically linking perceived value, and mobile shopping intention gives support to this mediating role of CS (Oliver 1993). Besides, there is another past study found that perceived value, customer satisfaction, and mobile shopping intention are all significant correlated (Chen and Lin 2019; Kim, Chan, and Gupta 2007). Thus, this study predicts that customer satisfaction mediates the perceived value and mobile shopping intention.

$\mathrm{H} 5 \mathrm{~d}$ : The relationship between perceived value (PV) and mobile shopping intention (MSI) is positively mediated by customer satisfaction (CS).

\subsection{Proposed conceptual framework}

Figure 1 below illustrates the proposed framework of Mobile Shopping Intention, which is based on the hypotheses proposed above. All constructs of E-servicecape were proposed to have direct effect with perceived value and customers satisfaction was proposed to mediate the relationship of perceived value and mobile shopping intention. 
Figure 1 Proposed conceptual framework

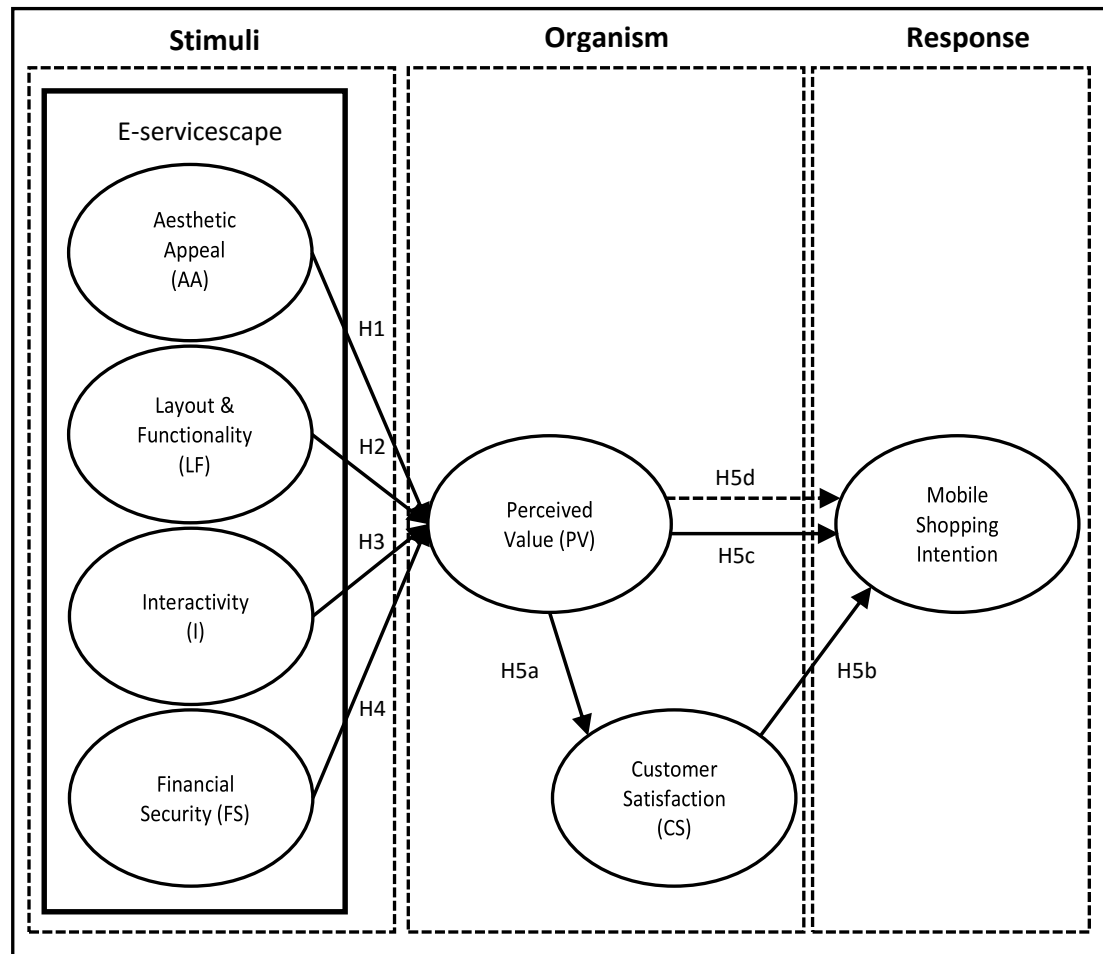

Source: Authors' synthesis, 2021

\section{Research Methodology}

\subsection{Research design and measurement of constructs}

We used positivist and cross-sectional design to amass our data within a limited timeframe of two months. Since our respondents were Gen X mobile users, the questionnaires were prepared in bilingual, both English and Chinese language. The survey instrument is divided two parts. Demographics information on the Part I for descriptive purposes, whereas Part II covered four specific constructs such as E-servicescape (ES), perceived value (PV), customer satisfaction (CS), and mobile shopping intention (MSI) with the 7-point Likert scale, ranging from " 1 = Strongly Disagree" to "7 = Strongly Agree. There are 26 respondents that age within 35 to 55 will be pre-test and must show from ambiguity as well as able to complete within 15 to 20 minutes. This pre-test is to ensure the questionnaire terms and phrases are understood by the respondent. Some minor change is expected to be done after the pre-test.

The shortened version of e-servicescape items has adapted from Harris and Goode (2010). The E-servicescape is divided of four measures, nine scales and 39 items adapted from; the items were classified into the following four dimensions: "aesthetic appeal", "layout and functionality", "interactivity" and "financial security". "Aesthetic appeal" with a total 
of 10 items. It includes visual appeal (5 items), and entertainment value (5 items). Next, "layout and functionality" with a total of 18 items. It involves usability (9 items), the relevance of information (4 items), customization/personalisation (5 items). Moreover, "Interactivity" with a total of 5 items. Furthermore, "financial security" with a total of 10 items. It comprehends ease of payment ( 3 items) and perceived security ( 3 items). Furthermore, this study adopts 4 items for perceived value from Kim, Chan, and Gupta (2007). 4 items of customer satisfaction were adapted from Janda, Trocchia, and Gwinner (2002); Oliver (1993). For measuring mobile shopping intention, 3 items were adapted from existing scales Ko, Kim, and Lee (2009), two items were adapted from Lu and Su (2009), and 1 item was adapted from Aldas-Manzano, Ruiz-Mafe, and Sanz-Blas (2009).

\subsection{Sample and data collection}

The target population for this research will be concentrated on generation $\mathrm{X}$, which aged around 35-55. The non-probability sampling technique is adopted in this study. Nonprobability sampling depends on the researchers' personal assessment rather than the opportunity to select sample elements (Malhotra and Dash 2016). Therefore, judgemental sampling and snowball sampling technique are chosen for this study. Furthermore, the present study performed a Structural Equation Modeling (SEM) analysis Hair et al. (2017b) and Cassel, Hackl, and Westlund (1999) believe that PLS-SEM is effective with 231 respondents.

SPSS version 25.0 and SmartPLS 3.0 software are chosen to perform data analysis to gain a holistic and full understanding of the research findings. Cohen, Manion, and Morrison (2018) mentioned that SPSS software enables the researcher to clarify the data analysis more effectively than other software programs. Furthermore, SmartPLS 3.0 version software is adapted in this study and is used to carry out the Partial Least Squares Structural Equation Modelling ("PLS-SEM") in this work.

\section{Data analysis and findings}

\subsection{Multicollinearity analysis}

Based on Table 1, the highest VIF value among all the construct is 4.444 , which has met below the threshold value of 5 (i.e., VIF $\leq 5$ ) (Hair et al. 2014). In addition, Hair et al. (2014) suggested that the threshold value for the independent construct is more than 0.1. Hence, as shown in Table 1, all the independent construct of the tolerance values is more than 0.1 .

Table 1 Multicollinearity analysis

\begin{tabular}{ccc}
\hline Variable & Tolerance & VIF \\
\hline Aesthetic Appeal & 0.260 & 3.849 \\
\hline
\end{tabular}




$\begin{array}{ccc}\text { Layout \& Functionality } & 0.239 & 4.192 \\ \text { Interactivity } & 0.304 & 3.287 \\ \text { Financial Security } & 0.412 & 2.426\end{array}$

Dependent Variable: Perceived Value

$\begin{array}{ccc}\text { Aesthetic Appeal } & 0.227 & 4.413 \\ \text { Layout \& Functionality } & 0.225 & 4.444 \\ \text { Interactivity } & 0.272 & 3.674 \\ \text { Financial Security } & 0.405 & 2.470 \\ \text { Perceived Value } & 0.244 & 4.102 \\ \text { Customer Satisfaction } & 0.263 & 3.803\end{array}$

Dependent Variable: Mobile Shopping Intention

Source: Authors' synthesis, 2021

\subsection{Demographic profile}

According to Table 2, a total of 231 respondents were interviewed. There is a total of 104 male and 107 female, and the remaining 20 respondents prefer not to reveal their gender. Therefore, the result indicates that the female respondent is more than male respondents. Next, on the question of age, most respondents are within the range of 33.3 per cent between 35 and 40 years old, followed by $31.6 \%$ of the respondents were between the ages of 41 to 45 years old, and $19.9 \%$ of respondents were between the ages of 46 to 50 years old and only $15.2 \%$ of respondents were between the ages of 51 to 55 years old. The age that below 34 and age above 56 have been filtered out for disqualification of this research. As the target respondent for this research is only for age between 35 to 55 years old.

Regarding the respondent income level, most of the respondents are not willing to reveal how much they earn monthly, while the $18.2 \%$ respondent's monthly income is fall between RM 3501- 4500 which are most of the respondent earned. Followed with $17.7 \%$ respondent earned more than RM5001. There are $16 \%$ of respondents earned around RM4501- RM5000. Followed with only $8.2 \%$ and $7.8 \%$ are earned between RM2501RM3500 and below RM2500. On the question of highest education level, a majority of $39 \%$ of the respondents are Certificate, followed by the Diploma holders accounting for $32.5 \%, 24.2 \%$ of bachelor's degree Holder. Lastly, the remaining $4.3 \%$ of respondents are the Postgraduate Degree holder. With respect to the mobile usage frequency, most of the respondent $58.4 \%$ used their mobile for shopping 4 hours and above. Surprisingly, this result shows that most of the respondents in Generation $X$ are heavy mobile shopping users. Followed with $27.3 \%$ respondent shop by using their mobile for around 3 hours, $9.1 \%$ respondent used for mobile shopping for 2 hours. Lastly, the remaining $5.2 \%$ use less than 1 hour. Finally, in terms of mobile usage familiarity, most of the respondents are familiar in using mobile phone accounting for $36.8 \%$. There are 29.8 of respondents have 
HOLISTICA Vol 12, Issue 2, 2021, pp.64-92

no comment which is neutral. Followed with $26.0 \%$ of the respondents are strongly familiar in using a mobile phone, 3.9\% of respondents are not familiar, and the remaining $3.5 \%$ are strongly not familiar in using the mobile phone.

Table 2 Demographic profile

\begin{tabular}{|c|c|c|}
\hline Demographic variable & Frequency & Percentage \\
\hline \multicolumn{3}{|l|}{ Gender } \\
\hline Male & 104 & 45.0 \\
\hline Female & 107 & 46.3 \\
\hline Prefer not to say & 20 & 8.7 \\
\hline \multicolumn{3}{|l|}{ Age group } \\
\hline 35 to 40 years old & 77 & 33.3 \\
\hline 41 to 45 years old & 73 & 31.6 \\
\hline 46 to 50 years old & 46 & 19.9 \\
\hline 51 to 55 years old & 35 & 15.2 \\
\hline \multicolumn{3}{|l|}{ Income } \\
\hline Less than 2500 & 19 & 8.2 \\
\hline $2501-3500$ & 18 & 7.8 \\
\hline $3501-4500$ & 42 & 18.2 \\
\hline $4501-5000$ & 37 & 16.0 \\
\hline 5001 and above & 41 & 17.7 \\
\hline Prefer not to say & 74 & 32 \\
\hline \multicolumn{3}{|c|}{ Highest educational level } \\
\hline Certificate & 90 & 39.0 \\
\hline Diploma & 75 & 32.5 \\
\hline Bachelor's degree & 56 & 24.2 \\
\hline Postgraduate Degree (Master / Doctoral) & 10 & 4.3 \\
\hline \multicolumn{3}{|c|}{ Mobile shopping frequency usage } \\
\hline Less than 1 hour & 12 & 5.2 \\
\hline 2 hours & 21 & 9.1 \\
\hline 3 hours & 63 & 27.3 \\
\hline 4 hours and above & 135 & 58.4 \\
\hline \multicolumn{3}{|c|}{ Mobile usage familiarity } \\
\hline Strongly not familiar & 8 & 3.5 \\
\hline Not familiar & 9 & 3.9 \\
\hline Neutral & 69 & 29.8 \\
\hline Familiar & 85 & 36.8 \\
\hline Strongly Familiar & 60 & 26.0 \\
\hline
\end{tabular}


Source: Authors' synthesis, 2021

\subsection{Correlation analysis}

A Pearson coefficient of correlations between Aesthetic Appeal (AA), Layout \& Functionality (LF), Interactivity (I), Financial Security (FS), Perceived Value (PV), Mobile Shopping Intention (MSI), and Customer Satisfaction (CS) was developed (refer Table 3) to explore the nature and signification of the relationships. Cohen (1988) suggested that $r>0.5$ indicated a large effect size. Thus, the result in Table 3 indicated a large effect size and positive association between LF, I, PV, MSI, CS respectively towards AA, where the $r$ $=0.642,0.824,0.789,0.833,0.765$ at the 0.01 significant level. While, FS has a small effect size and positive association toward the AA, where $r=0.104$. Similarly, LF has strong and positive correlation with I $(r=0.600)$, FS $(r=0.644), P V(r=0.619), M S I(r=0.596), C S(r=$ 0.600 ) at the 0.01 significant level. Moreover, I have a strong and positive correlation with PV $(r=759), M S I(r=830)$, and CS $(r=0.755)$ at the 0.01 significant level. However, this study has a weak and positive correlation with FS $(r=0.097)$. On the other hand, FS has a weak and positive correlation with PV $(r=0.139), \mathrm{MSI}(r=0.060)$, and $(r=0.117)$ at the 0.01 significant level. In addition, PV has a strong and positive correlation with MSI ( $r=$ $0.810)$ and $C S(r=0.830)$ at the 0.01 significant level. Lastly, there is a strong and positive correlation between MSI and CS (0.807) with large effect size at the 0.01 significant level. Over the result, AA toward the MSI has the strongest and largest correlation where $(r=$ 0.833).

Table 3 Assessment of correlation between variables

\begin{tabular}{cccccccccc}
\hline Constructs & Mean & S.D. & AA & LF & I & FS & PV & MSI & CS \\
\hline AA & 52.32 & 7.188 & 1 & & & & & \\
LF & 95.63 & 10.00 & $0.642^{* *}$ & 1 & & & & \\
I & 26.57 & 3.752 & $0.824^{* *}$ & 0.600 & 1 & & & \\
FS & 32.30 & 4.345 & $0.104^{* *}$ & 0.644 & 0.097 & 1 & & \\
PV & 21.11 & 3.276 & $0.789^{* *}$ & $0.619^{* *}$ & 0.759 & 0.139 & 1 & \\
MSI & 32.21 & 4.704 & $0.833^{* *}$ & $0.596^{*}$ & $0.830^{*}$ & 0.060 & $0.810^{*}$ & 1 \\
CS & 20.76 & 3.173 & $0.765^{* *}$ & $0.600^{*}$ & $0.755^{*}$ & 0.117 & $0.830^{*}$ & $0.807^{*}$ & 1
\end{tabular}

**Correlation is significant at the 0.01 level.

*Correlation is significant at the 0.05 level.

Abbreviation Note: Aesthetic Appeal (AA), Layout \& Functionality (LF), Interactivity (I), Financial Security (FS), Perceived Value (PV), Mobile Shopping Intention (MSI), and Customer Satisfaction (CS)

Source: Authors' synthesis, 2021 


\subsection{Construct validity and reliability}

The purpose of this section is to assess and evaluate the accuracy of the variable measure, which include reliability and validity. Three assessments were carried out through PLSSEM software, including the Cronbach's alpha, composite reliability, and DijkstraHenseler's rho (Hair et al. 2017b). Table 4 indicates the scale of 11 constructs that adopted in this research. The Cronbach's alpha, composite reliability, and Dijkstra-Henseler's rho value from the table 4 are more than 0.7 , which suggested by Dijkstra and Henseler (2015); Gefen, Rigdon, and Straub (2011); Hair et al. (2014). It has been assumed that the study constructs fulfil the internal consistency requirement.

Table 4 Assessment of internal consistency (PLS-SEM)

\begin{tabular}{cccc}
\hline Construct & Cronbach's Alpha, $\boldsymbol{\alpha}$ & $\begin{array}{c}\text { Composite reliability, } \\
\boldsymbol{\rho} \mathbf{c}\end{array}$ & $\begin{array}{c}\text { Dijkstra-Henseler's Rho, } \\
\boldsymbol{\rho} \text { A }\end{array}$ \\
\hline VA & 0.841 & 0.887 & 0.844 \\
EV & 0.81 & 0.868 & 0.815 \\
U & 0.931 & 0.941 & 0.966 \\
RI & 0.804 & 0.872 & 0.805 \\
C & 0.864 & 0.902 & 0.866 \\
I & 0.851 & 0.893 & 0.853 \\
EP & 0.778 & 0.863 & 0.894 \\
PS & 0.757 & 0.86 & 0.764 \\
PV & 0.854 & 0.902 & 0.86 \\
CS & 0.848 & 0.898 & 0.849 \\
MSI & 0.869 & 0.902 & 0.871
\end{tabular}

Abbreviation Note: Visual Appeal (VA), Entertainment Value (EV), Usability (U), Relevance of Information (RI), Customization/Personalization (C), Interactivity (I), Ease of Payment (EP), Perceived Security (PS), Perceived Value (PV), Mobile Shopping Intention (MSI), and Customer Satisfaction (CS).

Source: Authors' synthesis, 2021

\subsection{Validity - Confirmatory factor analysis (CFA) (PLS-SEM)}

This study conducts convergent and discriminative validity assessments via CFA through PLS-SEM to evaluate the measurement model's accuracy (Hair et al. 2017a).

\subsubsection{First order measurement model}

Figure 2 illustrates that all indicators for each construct (i.e., VA, EV, U, RI, C, I, EP, PS, PV, $\mathrm{CS}, \mathrm{MSI}$ ) are based on the theoretical foundations of the constructs and are treated as reflective models. 
Figure 2 First order measurement model

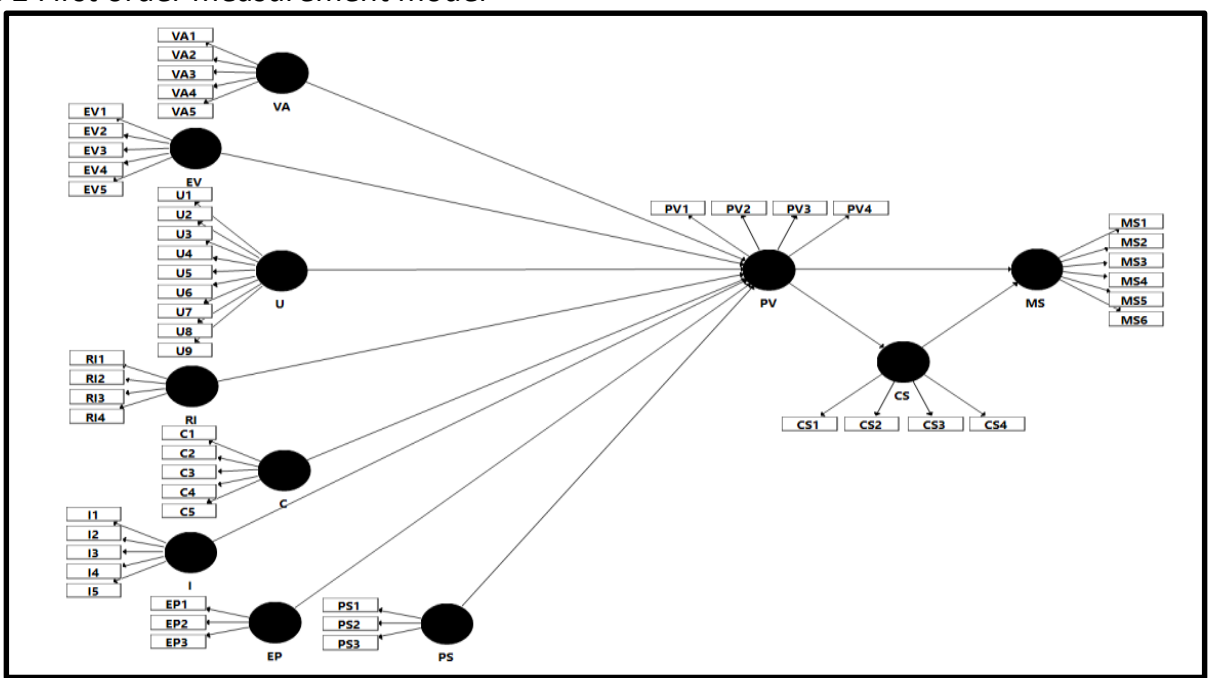

Source: Model extracted from Smart-PLS, 2021

The convergent validity in this study is tested through the factor loadings and average variance extracted (AVE). According to Hair et al. (2017b), the value of the rule of thumb should at least 0.708 . Hair et al. (2017b) further recommended that the AVE value should be at least 0.5 . Refer to table 5 indicates the factor loading for the first-order measurement model and most of the items, ranging from 0.701 to 0.905 which has met the recommended value of loadings by Hair et al. (2017b), which is 0.708 . However, the U1 (loadings $=0.701$ ), which is less than 0.708, Hair et al. (2017a) further suggested that the loading value of 0.700 is acceptable because it is close enough to 0.708 . Therefore, the $U 1$ is acceptable. Besides, most of the items has also met the recommended AVE value of 0.5 . In conclusion, the study constructs fulfil the convergent validity requirement.

Table 5 First order convergent validity

\begin{tabular}{cccc}
\hline Construct & Items & Loadings & AVE \\
\hline VA & VA1 & 0.773 & 0.612 \\
VA2 & 0.806 & \\
VA3 & 0.785 & \\
VA4 & 0.771 & \\
VA5 & 0.774 & 0.569 \\
EV & EV1 & 0.745 & \\
& EV2 & 0.72 & \\
& EV3 & 0.812 & \\
& EV4 & 0.732 & \\
& EV5 & 0.759 & \\
\hline
\end{tabular}




\begin{tabular}{|c|c|c|c|}
\hline \multirow[t]{9}{*}{ U } & U1 & 0.701 & \multirow[t]{9}{*}{0.640} \\
\hline & U2 & 0.754 & \\
\hline & U3 & 0.806 & \\
\hline & U4 & 0.798 & \\
\hline & U5 & 0.83 & \\
\hline & U6 & 0.835 & \\
\hline & U7 & 0.848 & \\
\hline & U8 & 0.79 & \\
\hline & U9 & 0.829 & \\
\hline \multirow[t]{4}{*}{ RI } & RI1 & 0.778 & \multirow[t]{4}{*}{0.630} \\
\hline & $\mathrm{R} / 2$ & 0.779 & \\
\hline & RI3 & 0.798 & \\
\hline & RI4 & 0.82 & \\
\hline \multirow[t]{5}{*}{$C$} & $\mathrm{C} 1$ & 0.824 & \multirow[t]{5}{*}{0.648} \\
\hline & $\mathrm{C} 2$ & 0.787 & \\
\hline & $\mathrm{C} 3$ & 0.822 & \\
\hline & $\mathrm{C} 4$ & 0.787 & \\
\hline & C5 & 0.806 & \\
\hline \multirow[t]{5}{*}{1} & 11 & 0.803 & \multirow[t]{5}{*}{0.626} \\
\hline & 12 & 0.762 & \\
\hline & 13 & 0.805 & \\
\hline & 14 & 0.797 & \\
\hline & 15 & 0.79 & \\
\hline \multirow[t]{3}{*}{ EP } & EP1 & 0.722 & \multirow[t]{3}{*}{0.680} \\
\hline & EP2 & 0.905 & \\
\hline & EP3 & 0.837 & \\
\hline \multirow[t]{3}{*}{ PS } & PS1 & 0.836 & \multirow[t]{3}{*}{0.672} \\
\hline & PS2 & 0.799 & \\
\hline & PS3 & 0.823 & \\
\hline \multirow[t]{4}{*}{ PV } & PV1 & 0.848 & \multirow[t]{4}{*}{0.696} \\
\hline & PV2 & 0.867 & \\
\hline & PV3 & 0.76 & \\
\hline & PV4 & 0.859 & \\
\hline \multirow[t]{2}{*}{ CS } & CS1 & 0.818 & \multirow[t]{2}{*}{0.687} \\
\hline & CS2 & 0.82 & \\
\hline
\end{tabular}




$\begin{array}{ccc} & \text { CS3 } & 0.848 \\ \text { MSI } & \text { MS4 } & 0.83 \\ & \text { MSI2 } & 0.819 \\ & \text { MSI3 } & 0.799 \\ & \text { MSI4 } & 0.735 \\ & \text { MSI5 } & 0.744 \\ & \text { MSI6 } & 0.813\end{array}$

Abbreviation Note: Visual Appeal (VA), Entertainment Value (EV), Usability (U), Relevance of Information (RI), Customization/Personalization (C), Interactivity (I), Ease of Payment (EP), Perceived Security (PS), Perceived Value (PV), Mobile Shopping Intention (MSI), and Customer Satisfaction (CS).

Source: Authors' synthesis, 2021

Table 6 shows the result of the discriminant validity by comparing the cross-loadings between the constructs. Ramayah et al. (2018), recommended that the value should load high on its own construct and low on other constructs. Based on the result that shows on table 6, all the indicators are loading high on its own constructs but low on other constructs, which has met the requirement of under cross-loadings.

Table 6 Second order cross-loadings

\begin{tabular}{cccccccccccc}
\hline & C & CS & EP & EV & I & MS & PS & PV & RI & U & VA \\
\hline C1 & 0.824 & 0.674 & 0.021 & 0.692 & 0.659 & 0.705 & 0.006 & 0.676 & 0.627 & 0.037 & 0.67 \\
C2 & 0.787 & 0.624 & 0.129 & 0.613 & 0.597 & 0.635 & 0.115 & 0.642 & 0.592 & 0.125 & 0.612 \\
C3 & 0.822 & 0.682 & 0.143 & 0.647 & 0.636 & 0.656 & 0.072 & 0.681 & 0.612 & 0.101 & 0.628 \\
C4 & 0.787 & 0.604 & 0.149 & 0.615 & 0.635 & 0.628 & 0.111 & 0.604 & 0.6 & 0.121 & 0.582 \\
C5 & 0.806 & 0.675 & 0.077 & 0.647 & 0.672 & 0.69 & 0.117 & 0.703 & 0.652 & 0.081 & 0.651 \\
CS1 & 0.632 & 0.818 & 0.104 & 0.562 & 0.617 & 0.672 & 0.1 & 0.665 & 0.561 & 0.114 & 0.579 \\
CS2 & 0.652 & 0.82 & 0.132 & 0.589 & 0.619 & 0.637 & 0.075 & 0.689 & 0.582 & 0.123 & 0.567 \\
CS3 & 0.697 & 0.848 & 0.071 & 0.602 & 0.649 & 0.66 & 0.09 & 0.686 & 0.639 & 0.107 & 0.596 \\
CS4 & 0.707 & 0.83 & 0.122 & 0.622 & 0.62 & 0.713 & 0.041 & 0.712 & 0.597 & 0.061 & 0.624 \\
EP1 & 0.06 & 0.053 & 0.722 & 0.021 & 0.036 & 0.009 & 0.573 & 0.051 & 0.008 & 0.612 & 0.047 \\
EP2 & 0.145 & 0.14 & 0.905 & 0.122 & 0.117 & 0.092 & 0.478 & 0.12 & 0.157 & 0.599 & 0.164 \\
EP3 & 0.082 & 0.101 & 0.837 & 0.101 & 0.073 & 0.023 & 0.52 & 0.083 & 0.081 & 0.597 & 0.077 \\
EV1 & 0.614 & 0.559 & 0.035 & 0.745 & 0.593 & 0.584 & 0.042 & 0.57 & 0.576 & 0.011 & 0.602 \\
EV2 & 0.572 & 0.516 & 0.093 & 0.72 & 0.523 & 0.528 & 0.091 & 0.532 & 0.561 & 0.12 & 0.545 \\
EV3 & 0.669 & 0.599 & 0.074 & 0.812 & 0.69 & 0.624 & 0.032 & 0.633 & 0.663 & 0.029 & 0.619 \\
\hline
\end{tabular}




\begin{tabular}{|c|c|c|c|c|c|c|c|c|c|c|c|}
\hline EV4 & 0.57 & 0.487 & 0.13 & 0.732 & 0.59 & 0.559 & 0.073 & 0.542 & 0.635 & 0.109 & 0.511 \\
\hline EV5 & 0.578 & 0.535 & 0.054 & 0.759 & 0.649 & 0.556 & 0.005 & 0.494 & 0.629 & 0.024 & 0.528 \\
\hline I1 & 0.607 & 0.594 & 0.107 & 0.646 & 0.803 & 0.658 & 0.105 & 0.616 & 0.651 & 0.066 & 0.577 \\
\hline 12 & 0.641 & 0.581 & 0.116 & 0.629 & 0.762 & 0.657 & 0.077 & 0.567 & 0.633 & 0.083 & 0.605 \\
\hline 13 & 0.665 & 0.641 & 0.01 & 0.668 & 0.805 & 0.678 & 0.039 & 0.586 & 0.654 & 0.035 & 0.593 \\
\hline 14 & 0.645 & 0.615 & 0.065 & 0.616 & 0.797 & 0.66 & 0.029 & 0.657 & 0.608 & 0.058 & 0.608 \\
\hline 15 & 0.59 & 0.556 & 0.107 & 0.645 & 0.79 & 0.625 & 0.083 & 0.583 & 0.676 & 0.066 & 0.534 \\
\hline MSI1 & 0.72 & 0.688 & 0.08 & 0.684 & 0.717 & 0.819 & 0.134 & 0.679 & 0.672 & 0.137 & 0.667 \\
\hline MSI2 & 0.662 & 0.607 & 0.033 & 0.569 & 0.635 & 0.799 & 0.052 & 0.638 & 0.615 & 0.039 & 0.602 \\
\hline MSI3 & 0.616 & 0.582 & 0.016 & 0.65 & 0.701 & 0.735 & 0.042 & 0.604 & 0.658 & 0.007 & 0.57 \\
\hline MSI4 & 0.66 & 0.631 & 0.09 & 0.609 & 0.632 & 0.744 & 0.065 & 0.637 & 0.605 & 0.101 & 0.611 \\
\hline MSI5 & 0.632 & 0.668 & 0.062 & 0.571 & 0.626 & 0.813 & 0.063 & 0.646 & 0.567 & 0.102 & 0.67 \\
\hline MSI6 & 0.544 & 0.593 & 0.012 & 0.442 & 0.549 & 0.751 & 0.022 & 0.575 & 0.533 & 0.018 & 0.593 \\
\hline PS1 & 0.066 & 0.089 & 0.5 & 0.018 & 0.052 & 0.057 & 0.836 & 0.14 & 0.02 & 0.551 & 0.05 \\
\hline PS2 & 0.089 & 0.074 & 0.512 & 0.015 & 0.063 & 0.07 & 0.799 & 0.112 & 0.046 & 0.662 & 0.083 \\
\hline PS3 & 0.103 & 0.063 & 0.477 & 0.075 & 0.091 & 0.058 & 0.823 & 0.134 & 0.102 & 0.642 & 0.129 \\
\hline PV1 & 0.7 & 0.7 & 0.092 & 0.614 & 0.634 & 0.653 & 0.137 & 0.848 & 0.596 & 0.08 & 0.619 \\
\hline PV2 & 0.733 & 0.744 & 0.086 & 0.673 & 0.696 & 0.743 & 0.135 & 0.867 & 0.692 & 0.132 & 0.677 \\
\hline PV3 & 0.58 & 0.61 & 0.019 & 0.573 & 0.557 & 0.618 & 0.063 & 0.76 & 0.516 & 0.029 & 0.564 \\
\hline PV4 & 0.722 & 0.71 & 0.165 & 0.603 & 0.647 & 0.688 & 0.185 & 0.859 & 0.636 & 0.212 & 0.616 \\
\hline RI1 & 0.542 & 0.506 & 0.097 & 0.637 & 0.607 & 0.573 & 0.089 & 0.572 & 0.778 & 0.142 & 0.572 \\
\hline $\mathrm{R} / 2$ & 0.572 & 0.526 & 0.122 & 0.601 & 0.612 & 0.596 & 0.099 & 0.558 & 0.779 & 0.136 & 0.575 \\
\hline $\mathrm{RI3}$ & 0.661 & 0.62 & 0.13 & 0.674 & 0.682 & 0.675 & 0.04 & 0.615 & 0.798 & 0.069 & 0.62 \\
\hline RI4 & 0.653 & 0.621 & 0.035 & 0.664 & 0.678 & 0.637 & 0.006 & 0.587 & 0.82 & 0.043 & 0.569 \\
\hline U1 & 0.073 & 0.043 & 0.5 & 0.081 & 0.025 & 0.016 & 0.569 & 0.071 & 0.119 & 0.701 & 0.099 \\
\hline U2 & 0.066 & 0.047 & 0.515 & 0.017 & 0.073 & 0.034 & 0.584 & 0.072 & 0.084 & 0.754 & 0.035 \\
\hline U3 & 0.156 & 0.124 & 0.54 & 0.103 & 0.121 & 0.137 & 0.591 & 0.152 & 0.16 & 0.806 & 0.161 \\
\hline U4 & 0.007 & 0.063 & 0.518 & 0.011 & 0.022 & 0.029 & 0.58 & 0.063 & 0.048 & 0.798 & 0.061 \\
\hline U5 & 0.116 & 0.141 & 0.584 & 0.087 & 0.027 & 0.07 & 0.599 & 0.148 & 0.094 & 0.83 & 0.141 \\
\hline U6 & 0.074 & 0.109 & 0.602 & 0.066 & 0.042 & 0.056 & 0.624 & 0.11 & 0.073 & 0.835 & 0.082 \\
\hline U7 & 0.078 & 0.118 & 0.612 & 0.036 & 0.065 & 0.04 & 0.603 & 0.142 & 0.069 & 0.848 & 0.093 \\
\hline U8 & 0.088 & 0.07 & 0.623 & 0.043 & 0.077 & 0.048 & 0.606 & 0.058 & 0.109 & 0.79 & 0.09 \\
\hline U9 & 0.09 & 0.063 & 0.641 & 0.051 & 0.085 & 0.081 & 0.695 & 0.081 & 0.098 & 0.829 & 0.102 \\
\hline VA1 & 0.597 & 0.546 & 0.163 & 0.598 & 0.544 & 0.586 & 0.126 & 0.612 & 0.555 & 0.147 & 0.773 \\
\hline VA2 & 0.665 & 0.588 & 0.024 & 0.628 & 0.662 & 0.695 & 0.021 & 0.624 & 0.62 & 0.004 & 0.806 \\
\hline
\end{tabular}


HOLISTICA Vol 12, Issue 2, 2021, pp.64-92

$\begin{array}{cccccccccccc}\text { VA3 } & 0.592 & 0.516 & 0.12 & 0.487 & 0.528 & 0.594 & 0.128 & 0.574 & 0.473 & 0.151 & 0.785 \\ \text { VA4 } & 0.558 & 0.554 & 0.074 & 0.576 & 0.519 & 0.56 & 0.059 & 0.5 & 0.582 & 0.074 & 0.771 \\ \text { VA5 } & 0.636 & 0.587 & 0.138 & 0.624 & 0.618 & 0.672 & 0.082 & 0.583 & 0.647 & 0.135 & 0.774\end{array}$

Abbreviation Note: Visual Appeal (VA), Entertainment Value (EV), Usability (U), Relevance of Information (RI), Customization/Personalization (C), Interactivity (I), Ease of Payment (EP), Perceived Security (PS), Perceived Value (PV), Mobile Shopping Intention (MSI), and Customer Satisfaction (CS).

Source: Authors' synthesis, 2021

\subsubsection{Second-order measurement model}

Figure 3 demonstrates the latent construct in second-order measurement model is measured based on the computation of EV, AA, C, RI, U, EP and PS. In particular, the EV and $V A$ latent construct in the first-order measurement are served as the indicators to measure the $A A$ latent construct in the second-order measurement model. Furthermore, the $\mathrm{C}, \mathrm{RI}$, and $\mathrm{U}$ latent construct in the first-order measurement are served as the indicators to measure the LF latent construct in the second-order measurement model. Lastly, the EP and PS latent construct in the first-order measurement are served as the indicators to measure the FS latent construct in the second-order measurement model. Other than that, the non-hierarchical construct, and other direct measurements (i.e., I, $\mathrm{PV}, \mathrm{CS}$, and $\mathrm{MSI}$ ) remain unchanged in the second model.

Figure 2 First order measurement model

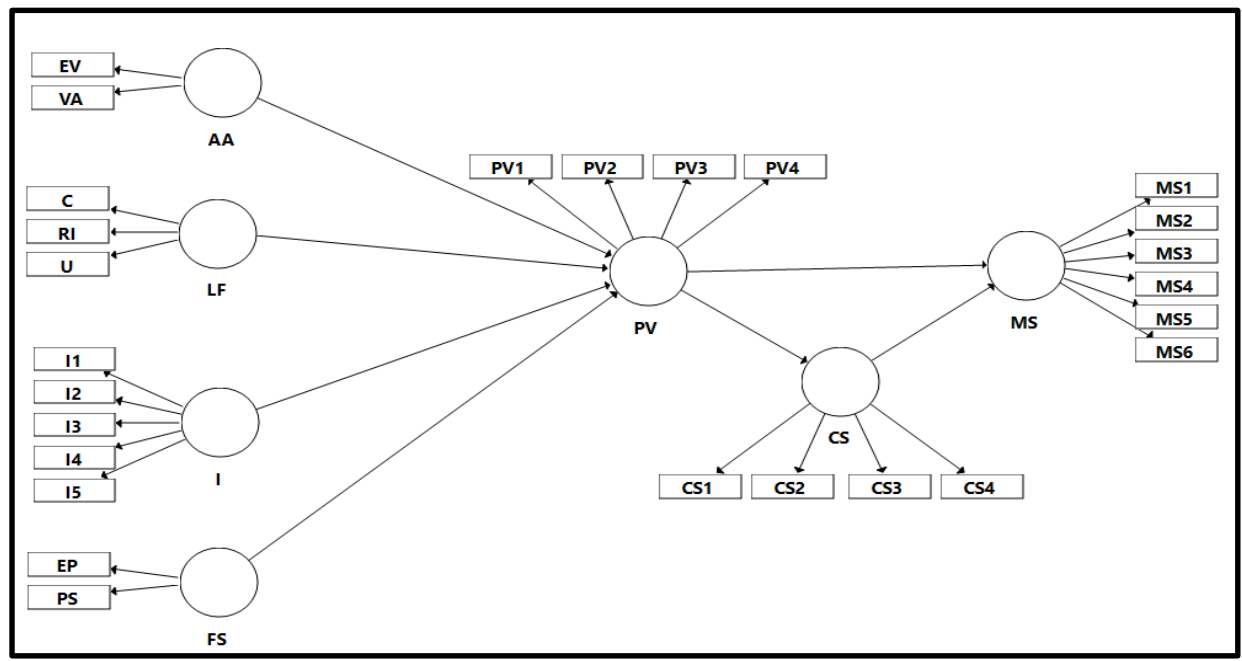

Source: Model extracted from Smart-PLS, 2021

Table 7 presents the factor loading for the second-order measurement model. Most of the loading values range from 0.735 to 0.942 , which has met the threshold value of 0.708 suggested by Hair et al. (2017a). However, one of the factors (U) (loadings = 0. 206), which 
HOLISTICA Vol 12, Issue 2, 2021, pp.64-92

is lower than the threshold value. In addition, Hair et al. (2017b) suggested that the AVE value should be more than 0.5 , as mentioned above. Then, Table 7 also presents that, all the AVE values are ranging from 0.598 to 0.873 , which have met the threshold value that suggests by the author. Thus, it is concluded that most of the constructs meet the convergent validity requirement except the Layout \& Functionality construct.

Table 7 Second-order convergent validity

\begin{tabular}{|c|c|c|c|}
\hline Latent Variables & Indicators/Factors & Loadings & AVE \\
\hline \multirow[t]{3}{*}{ Aesthetic Appeal (AA) } & EV & 0.934 & \\
\hline & & & 0.873 \\
\hline & VA & 0.935 & \\
\hline \multirow[t]{3}{*}{ Layout \& Functionality (LF) } & C & 0.942 & \\
\hline & $\mathrm{RI}$ & 0.930 & 0.598 \\
\hline & $U$ & 0.206 & \\
\hline \multirow[t]{5}{*}{ Interactivity (I) } & 11 & 0.803 & \\
\hline & 12 & 0.762 & \\
\hline & 13 & 0.805 & 0.626 \\
\hline & 14 & 0.797 & \\
\hline & 15 & 0.79 & \\
\hline \multirow[t]{3}{*}{ Financial Security (FS) } & EP & 0.855 & \\
\hline & & & 0.810 \\
\hline & PS & 0.943 & \\
\hline \multirow[t]{4}{*}{ Perceived Value (PV) } & PV1 & 0.847 & \\
\hline & PV2 & 0.867 & 0.696 \\
\hline & PV3 & 0.76 & \\
\hline & PV4 & 0.859 & \\
\hline \multirow[t]{4}{*}{ Customer Satisfaction (CS) } & CS1 & 0.818 & \\
\hline & CS2 & 0.82 & 0.687 \\
\hline & CS3 & 0.848 & \\
\hline & CS4 & 0.83 & \\
\hline \multirow[t]{6}{*}{ Mobile Shopping Intention (MSI) } & MSI1 & 0.819 & \\
\hline & MSI2 & 0.799 & \\
\hline & MSI3 & 0.735 & \\
\hline & MSI4 & 0.744 & 0.605 \\
\hline & MSI5 & 0.813 & \\
\hline & MSI6 & 0.751 & \\
\hline
\end{tabular}


Abbreviation Note: Aesthetic Appeal (AA), Layout \& Functionality (LF), Interactivity (I), Financial Security (FS), Perceived Value (PV), Mobile Shopping Intention (MSI), and Customer Satisfaction (CS).

Source: Authors' synthesis, 2021

Table 8 demonstrate the result of cross-loading for second-order measurement model. All the value load high on its own construct and low on other construct which has met the requirement of under cross-loadings.

Table 8 Second-order cross loadings

\begin{tabular}{|c|c|c|c|c|c|c|c|}
\hline Indicators & AA & CS & FS & I & LF & MS & PV \\
\hline VA & 0.935 & 0.714 & 0.130 & 0.737 & 0.808 & 0.797 & 0.744 \\
\hline EV & 0.934 & 0.717 & 0.076 & 0.809 & 0.850 & 0.758 & 0.739 \\
\hline CS1 & 0.610 & 0.818 & 0.114 & 0.617 & 0.637 & 0.672 & 0.665 \\
\hline $\mathrm{CS} 2$ & 0.619 & 0.820 & 0.110 & 0.619 & 0.659 & 0.637 & 0.689 \\
\hline CS3 & 0.641 & 0.848 & 0.092 & 0.649 & 0.711 & 0.660 & 0.686 \\
\hline CS4 & 0.667 & 0.830 & 0.083 & 0.620 & 0.692 & 0.713 & 0.712 \\
\hline EP & 0.126 & 0.130 & 0.854 & 0.102 & 0.197 & 0.058 & 0.111 \\
\hline PS & 0.081 & 0.092 & 0.931 & 0.084 & 0.162 & 0.074 & 0.158 \\
\hline 11 & 0.654 & 0.594 & 0.118 & 0.803 & 0.663 & 0.658 & 0.616 \\
\hline 12 & 0.660 & 0.581 & 0.104 & 0.762 & 0.675 & 0.657 & 0.567 \\
\hline 13 & 0.674 & 0.641 & 0.030 & 0.805 & 0.694 & 0.678 & 0.586 \\
\hline 14 & 0.655 & 0.615 & 0.049 & 0.797 & 0.662 & 0.660 & 0.657 \\
\hline 15 & 0.630 & 0.556 & 0.104 & 0.790 & 0.666 & 0.625 & 0.583 \\
\hline RI & 0.828 & 0.718 & 0.100 & 0.813 & 0.929 & 0.783 & 0.735 \\
\hline$U$ & 0.111 & 0.121 & 0.816 & 0.077 & 0.9 & 0.080 & 0.140 \\
\hline C & 0.846 & 0.811 & 0.126 & 0.795 & 0.942 & 0.824 & 0.539 \\
\hline MS1 & 0.723 & 0.688 & 0.125 & 0.717 & 0.743 & 0.819 & 0.679 \\
\hline MS2 & 0.627 & 0.607 & 0.049 & 0.635 & 0.673 & 0.799 & 0.639 \\
\hline MS3 & 0.653 & 0.582 & 0.020 & 0.701 & 0.665 & 0.81 & 0.604 \\
\hline MS4 & 0.653 & 0.631 & 0.083 & 0.632 & 0.673 & 0.799 & 0.637 \\
\hline MS5 & 0.664 & 0.668 & 0.070 & 0.626 & 0.639 & 0.813 & 0.646 \\
\hline MS6 & 0.554 & 0.593 & -0.009 & 0.549 & 0.563 & 0.826 & 0.575 \\
\hline PV1 & 0.660 & 0.700 & 0.132 & 0.634 & 0.689 & 0.653 & 0.847 \\
\hline PV2 & 0.722 & 0.744 & 0.128 & 0.696 & 0.760 & 0.743 & 0.867 \\
\hline PV3 & 0.608 & 0.610 & 0.050 & 0.557 & 0.578 & 0.618 & 0.760 \\
\hline
\end{tabular}




$\begin{array}{llllllll}\text { PV4 } & 0.652 & 0.710 & 0.197 & 0.647 & 0.733 & 0.688 & 0.859\end{array}$

Abbreviation Note: Aesthetic Appeal (AA), Layout \& Functionality (LF), Interactivity (I), Financial Security (FS), Perceived Value (PV), Mobile Shopping Intention (MSI), and Customer Satisfaction (CS).

Source: Authors' synthesis, 2021

\subsection{Assessment of structural model}

In order to analyse the model's predictive capabilities and the targeted relationships among its latent constructs (i.e., VA, EV, U, RI, C I, EP, PS, PV, CS, and MSI), a structural model evaluation should be carried out (Hair et al. 2017a). In this study, SmartPLS is used under a bootstrapping feature with 5.000 bootstrap samples that recommended by Hair et al. (2017b). The assessment of structural model includes the coefficient of determination $\left(R^{2}\right)$, effect size $\left(f^{2}\right)$, predictive relevance $\left(Q^{2}\right)$, and significance of the path coefficient.

\subsubsection{Assessment of the Coefficient of Determination, Effect Size and Predictive Relevance}

According to Hair et al. (2017b), the evaluation of the R2 level is significant as it shows the variance amount of the exogenous construct on endogenous constructs of the models. Table 9 indicates that all the values are more than 0.26 , which are in line with Cohen (1988). The R2 level for CS in this research is 0.690 , indicating that $69.0 \%$ of the total variance of this endogenous variable is explained by its exogenous variables, PV. In other words, $31 \%$ of the variation of CS is explained by other factors. Moreover, the total variance for MS is 0.718 , which reveals that $71.8 \%$ of the total variance of this endogenous variable is explained by its exogenous variables, including PV and CS. Lastly, the total variation explained for $P V$ is 0.711 , demonstrated that $A A, L F, I$, and $F S$ could explain $71.1 \%$ towards PV.

Table $9 R^{2}$ Assessment of the Structural Model

\begin{tabular}{ccc}
\hline Endogenous Variable & $\mathbf{R}^{\mathbf{2}}$ & Remarks for $\mathbf{R}^{\mathbf{2}}$ \\
\hline CS & 0.690 & Substantial \\
MS & 0.718 & Substantial \\
PV & 0.711 & Substantial
\end{tabular}

Abbreviation Note: Aesthetic Appeal (AA), Layout \& Functionality (LF), Interactivity (I), Financial Security (FS), Perceived Value (PV), Mobile Shopping Intention (MSI), and Customer Satisfaction (CS).

Source: Authors' synthesis, 2021

Other than, $R^{2}$ level assessment, this research also carried out effect size assessment $\left(f^{2}\right)$ to evaluate the weightings of the predictor on its endogenous variable (Ramayah et al. 2018). According to Cohen (1988)'s guideline, AA has a small size effect with $0.031 \mathrm{f}^{2}$ value 
on its endogenous variable, PV. FS, I, and LF, on the other hand, have a small effect on PV with $0.002,0.019$, and $0.147 \mathrm{f}^{2}$ value on its exogenous variables, respectively. As shown in the Table 10, CS and PV have a medium effect on MS with $\mathrm{f}^{2}$ value of 0.211 and 0.220 , respectively. Lastly, PV with $2.224 \mathrm{f}^{2}$ value has a substantial size effect on CS.

Table 10 Effect Size $\left(\mathrm{f}^{2}\right)$ of Endogenous Variables of the Structural Model

\begin{tabular}{ccccc}
\hline \multicolumn{1}{c}{ Variables } & & & $\mathbf{f}^{\mathbf{2}}$ & Effect size \\
\hline Endogenous Variables & $:$ & PV & & Small \\
Exogenous Variable & $:$ & AA & 0.031 & Small \\
Exogenous Variable & $:$ & FS & 0.002 & Small \\
Exogenous Variable & $:$ & I & 0.019 & Small \\
Exogenous Variable & $:$ & LF & 0.147 & Medium \\
Endogenous Variables & $:$ & MS & & Medium \\
Exogenous Variable & $:$ & CS & 0.211 & \\
Exogenous Variable & $:$ & PV & 0.220 & Substantial \\
Endogenous Variables & $:$ & CS & & 2.224 \\
Exogenous Variable & $:$ & PV & \\
Abbreviation Note: Aesthetic Appeal (AA), Layout \& Functionality (LF), Interactivity (I), \\
Financial Security (FS), Perceived Value (PV), Mobile Shopping Intention (MSI), and Customer \\
Satisfaction (CS).
\end{tabular}

Source: Authors' synthesis, 2021

This study examines Stone-Geisser's $Q^{2}$ to measure the overall predictive relevance of each endogenous construct in the path model (Geisser 1974; Ramayah et al. 2018; Stone 1974). As shown in table 11 , all values of endogenous variables including $C S\left(Q^{2}=0.451\right)$, MS $\left(Q^{2}=0.411\right)$, and $P V\left(Q^{2}=0.469\right)$ have an adequate predictive relevance effect in this research model as the values are more than zero according to Hair et al. (2017a).

Table 11 Stone-Geisser's $Q^{2}$ Assessment of the Structural Model

\begin{tabular}{ccc}
\hline Endogenous Variable & $\mathbf{Q}^{2}$ & ${\text { Remarks for } \mathbf{Q}^{\mathbf{2}}}^{\text {CS }}$ \\
MS & 0.451 & Sufficient \\
PV & 0.411 & Sufficient \\
CS & 0.469 & Sufficient
\end{tabular}

Abbreviation Note: Aesthetic Appeal (AA), Layout \& Functionality (LF), Interactivity (I), Financial Security (FS), Perceived Value (PV), Mobile Shopping Intention (MSI), and Customer Satisfaction (CS).

Source: Authors' synthesis, 2021 


\subsubsection{Path coefficients assessment}

There are total of 7 direct hypotheses has been developed to measure the significant level, $t$-statistics for all the paths that are performed by using the bootstrapping function of PLS-SEM software with 5,000 bootstrap samples. Table 12 demonstrates that, there are 6 relationships are estimated to be 0.05 or smaller in p-value (significance 1-tailed) (Hair et al. 2014).

Specifically, the predictors $A A(\beta=0.209, p=0.014)(H 1), L F(\beta==0.508, p=<0.01)(H 2)$, and I $(\beta=0.155, p=<0.01)(H 3)$ are positively related to PV. However, the FS $(\beta=0.022$, $p=0.275)(\mathrm{H} 4)$ is negatively related to PV. Moreover, $P V(\beta=0.831, p=<0.01)(H 5 a)$ is positively related to CS. Lastly, $C S(\beta=0.438, p=<0.01)(H 5 b)$ and $P V(\beta=0.448, p=<0.01)$ $(\mathrm{H} 5 \mathrm{c})$ are positively related to MSI. In sum, $\mathrm{H} 1, \mathrm{H} 2, \mathrm{H} 3, \mathrm{H} 5 \mathrm{a}, \mathrm{H} 5 \mathrm{~b}, \mathrm{H} 5 \mathrm{c}$ are supported except the $\mathrm{H} 4$ are not supported.

Table 12 Path Coefficients Assessment of the Structural Model

\begin{tabular}{ccccccc}
\hline Hypothesis & Relationship & $\begin{array}{c}\text { Std. } \\
\text { Beta }\end{array}$ & $\begin{array}{c}\text { Std. } \\
\text { Error }\end{array}$ & t-value & $\begin{array}{c}\text { Significance 1- } \\
\text { tailed }\end{array}$ & Decision \\
\hline H1 & AA $\rightarrow$ PV & 0.209 & 0.095 & 2.203 & 0.014 & Supported \\
H2 & LF $\rightarrow$ PV & 0.508 & 0.116 & 4.370 & $<0.01$ & Supported \\
H3 & I $\rightarrow$ PV & 0.155 & 0.087 & 1.792 & 0.036 & Supported \\
H4 & FS $\rightarrow$ PV & 0.022 & 0.037 & 0.599 & 0.275 & Not \\
& & & & & & Supported \\
H5a & PV $\rightarrow$ CS & 0.831 & 0.019 & 42.798 & $<0.01$ & Supported \\
H5b & CS $\rightarrow$ MSI & 0.438 & 0.062 & 7.029 & $<0.01$ & Supported \\
H5c & PV $\rightarrow$ MSI & 0.448 & 0.062 & 7.221 & $<0.01$ & Supported
\end{tabular}

Abbreviation Note: Aesthetic Appeal (AA), Layout \& Functionality (LF), Interactivity (I), Financial Security (FS), Perceived Value (PV), Mobile Shopping Intention (MSI), and Customer Satisfaction (CS).

Source: Authors' synthesis, 2021

\subsubsection{Mediation Effect Test}

Table 13 indicates the mediating results from bootstrapping. Hypothesis $\mathrm{H} 5 \mathrm{~d}$ is significant, where $(\beta=0.364)$ with $t-$-values of 7.001. The $p$-value of $\mathrm{H} 5 \mathrm{~d}$ is $<0.01$. The Boot $\mathrm{Cl} B S$ with the value of ( $L L=0.279 ; \mathrm{UL}=0.452$ ), which do not straddle a 0 in between and showing that there are mediating (Preacher and Hayes 2008). Thus, the H5d hypothesis is supported in which customer satisfaction (CS) mediate the relationship between perceived value (PV) and mobile shopping intention (MSI).

Table 13 Hypotheses testing on mediation

\begin{tabular}{lllllll} 
H & Relationship & $\begin{array}{l}\text { Std. } \\
\text { Beta }\end{array}$ & Std. & t-value & & \multicolumn{2}{c}{$95 \%$ Boot Cl BC } & Decision \\
& & Error & LL & UL & \\
\hline
\end{tabular}


HOLISTICA Vol 12, Issue 2, 2021, pp.64-92

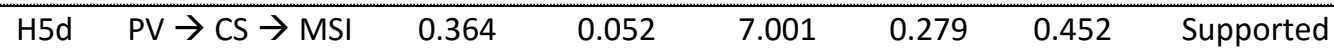

Abbreviation Note: Aesthetic Appeal (AA), Layout \& Functionality (LF), Interactivity (I), Financial Security (FS), Perceived Value (PV), Mobile Shopping Intention (MSI), and Customer Satisfaction (CS).

Source: Authors' synthesis, 2021

As suggested by lacobucci, Saldanha, and Deng (2007), the level of mediation effect could be divided into non, partial, or full mediates relationship, after an evaluation of the significance of the mediation effects.

Referring to Table 14, it has demonstrated that CS partially mediates the relationship between PV and MSI.

Table 14 Mediation types for indirect effects

$\begin{array}{cccccc}\text { H } & \text { Indirect path } & \text { Std. Beta } & \text { Direct path } & \text { PC } & \text { Mediation type } \\ \mathrm{H} 5 \mathrm{~d} & \mathrm{PV} \rightarrow \mathrm{CS} \rightarrow \mathrm{MSI} & 0.364 & \mathrm{PV} \rightarrow \mathrm{MSI} & 0.364 & \text { Partially mediated }\end{array}$

Note: $P C=$ Pact coefficient

Abbreviation Note: Aesthetic Appeal (AA), Layout \& Functionality (LF), Interactivity (I), Financial Security (FS), Perceived Value (PV), Mobile Shopping Intention (MSI), and Customer Satisfaction (CS).

Source: Authors' synthesis, 2021

\section{Conclusions and implications}

\subsection{Research implications}

The results of this current study verified the links between the research constructs. However, the application of S-O-R model is like the one that seen in most of the previous studies some of the conclusion has provided a useful context for further exploration of websites as e-servicescape (Wu et al. 2013; Yoon 2012). This research thus promotes the model of the servicescape and supports an extended conceptualization of the word that is consistent with the initial analysis by Bitner (1992). This study develops the effectiveness of the e-servicescape definition from the generation $X$ viewpoint, which includes the dimensions of aesthetic appeal, usability, customization, and financial security. It also reaffirmed those different aspects of the e-servicescape affect consumer reaction of online retailers significantly. The analyses revealed that the layout and functionality of an e-servicescape have the greatest impact on perceived value toward mobile purchase intention, and hence the research gaps that motivated this study have been addressed. Meanwhile, the impacts of e-servicescape dimensions on perceived value showed that a generalised process of value for the website could positively affect the reactions of customers through focal independent e-servicescape variables. It was worth noting that the findings of this study are in line with previous studies such as Karson and Fisher (2005), which related to brand and website attitude as well as purchase 
intention. This article then offers a clearer understanding of the process and a detailed analysis of how the e-servicescape dimensions exist in an online environment towards the literature. Due to the strong influence of e-servicescape on perceived value has been largely ignored in previous studies, our study attempted to deal with this problem by examining how e-servicescape generates perceived value to mobile purchase intention through the mediation of customer satisfaction. In addition, this study further presents more evidence that user experience in the creation of e-servicescape environments be considered when designing e-servicescape online shopping environments.

It was also interesting to note that this study helps to develop a positive stance towards an online retailer, ensure repeated buying intent and spread positive information of online shop to others, thus enhancing consumer reaction towards the reputation of the store and increasing the customer satisfaction to online customers especially in generation X. In this study, practical insights into how generation $X$ users are attracted and retained in social business are also provided. The findings emphasise the significant impact of perceived value on user satisfaction, which further influences the purpose in the commercial social environment of buying, which implies that service providers should take steps to build user satisfaction by enhancing the e-servicescape user-perceived value. In other words, this represents that the service providers can make their products value for money and efficient and find out what they want easily and quickly. For example, they may provide personalized recommendation service based on the generation $X$ users behaviours and preferences of consumers. Inevitably, the continuous improvement in eservicescape would lead to an increase in the perceived value. Our research also found that satisfaction influences behavioural intentions directly and positively and serves as a mediator between perceived value and mobile purchase intentions.

\subsection{Practical implications}

It was worth noting that managers responsible for the design of mobile commerce application should therefore consider these dimensions of the e-servicescape and incorporate them in the design of their online strategies to build perceived value and customer satisfaction predominantly based on generation X. Accordingly, the mobile app needs to invest in all dimensions of e-servicescape, specific in aesthetic appeal, layout and functionality and interactivity dimensions that had a stronger effect on perceived eshopping value. To enhance perceived value, online shops should make efforts to increase their websites' usability, manage the information required by online customers, customise various parts of their web pages to meet customer needs, and enable interaction with customers. For example, the users can set the word's size as most of generation $x$ are long sighted (Haigh 1993). Moreover, the aesthetic appeal refers to the visual aspect of web pages that creates the first impression and which can affect risk perception. Therefore, the manager can use more graphic design on the mobile commerce platform to attract the generation $\mathrm{X}$. Although the study showed that the financial security dimension of e-servicescape has no influence on perceived e-shopping value, online shops should not neglect this aspect of the offering. Therefore, the manager should also analyse mobile financial security. Mobile application managers should pay 
attention to the perceived security and payment option to enhance the trust and website value, providing privacy guarantees against the misuse of financial information. Finally, special attention should be placed on ensuring transaction security, investing in customer personal data protection, and informing customers regarding the use of their personal data.

In addition, It is imperative that customers should be convinced that they are getting high value from the providers. Our study shows that perceived value is one of contributing factors to satisfaction and mobile shopping intentions. The manager of mobile commerce should offer a wide variety of products/services, carefully evaluate price competition, and make the purchase from the website easier and efficient to increase customers' perceived value. In sum, the managerial implication here is that the mobile commerce platform manager can improve e-servicescape and the reflection of improved e-servicescape will increase perceived value, which combined in making customers satisfied which would then enhance their mobile shopping intentions. This is also further evidenced in a study conducted by Wang (2020).

\section{Recommendations for future research}

First and foremost, this research has shortened the version of the initial (Harris and Goode 2010) scale used to measure the e-servicescape dimensions to lessen the pressure on respondents. Consequently, the research results could not be entirely compared to studies which used the entire scale, hence limiting the chance of generalising results. Next, this study ignores the dynamic relationship between individual constructs. Experimental methods (such as conjoint analysis) can be used to study the relationship between e-servicescape and another important marketing construct in online environment, such as perceived risk, social media marketing, e-service quality, price perception and product quality and so on. By so doing, the causal relationship between various construct can be established to a large extent, which is impossible in crosssectional studies.

In addition, one of the e-servicescape components has a weak impact on perceived eshopping value, (e.g., financial security) which indicates that it is necessary to include other theoretical structures mentioned above and analyse the influence of moderating variables on the relationship between constructs. Lastly, this study only investigated the generation $X$ perception, which provides limited information to that online seller as the population of generation $\mathrm{X}$ are still lesser than generation $\mathrm{Y}$ and $\mathrm{Z}$.

Mediating variables between perceive value and mobile shopping intention in future studies could include another construct such as social media marketing, e-service quality, and price perception. The moderating variable can be included in future studies as wellfor example, gender, the level of shop personalisation, environment atmospherics and manner of product presentation. Moreover, future research can focus on the impact of language on e-servicescape perception toward mobile shopping intention. It might be 


\section{HOLISTICA Vol 12, Issue 2, 2021, pp.64-92}

interesting to compare the perception of servicescape between online shopping and real shopping to investigate the difference between servicescape elements in a real environment and web-based environment. Other than that, the weak links between some constructs indicate that there may be unobserved heterogeneity (Hair et al. 2014). Future studies may address the said issue.

\section{References}

Aldas-Manzano, J., Ruiz-Mafe, C., \& Sanz-Blas, S. (2009). Mobile Commerce Adoption in Spain: The Influence of Consumer Attitudes and Ict Usage Behaviour. In Mobile Business: Technical, Methodological and Social Perspectives, 282-292. London: IGI Global.

Anderson, R.E., \& Srinivasan, S.S. (2003). E-Satisfaction and E-Loyalty: A Contingency Framework. Psychology \& marketing, 20, no. 2: 123-138. https://dx.doi.org/10.1002/MAR.10063.

Ballantine, P.W. (2005). Effects of Interactivity and Product Information on Consumer Satisfaction in an Online Retail Setting. International journal of retail \& distribution management, 33, no. 6: 461-471. https://dx.doi.org/10.1108/09590550510600870.

Bauer, H.H., Falk, T., \& Hammerschmidt, M. (2006). Etransqual: A Transaction Process-Based Approach for Capturing Service Quality in Online Shopping. Journal of business research, 59, no. 7: 866-875. https://dx.doi.org/10.1016/J.JBUSRES.2006.01.021.

Bitner, M.J. (1992). Servicescapes: The Impact of Physical Surroundings on Customers and Employees. Journal of marketing, 56, no. 2: 57-71. https://dx.doi.org/10.2307/1252042.

Bolton, R.N., \& Drew, J.H. (1991). A Multistage Model of Consumer Feelings and Purchase Likelihood. Psychology and Marketing, 9: 347-363.

Brady, M.K., \& Robertson, C.J. (1999). An Exploratory Study of Service Value in the USA and Ecuador. International journal of service industry management, 10, no. 5: 469-486. https://dx.doi.org/10.1108/09564239910289003.

Brady, M.K., Robertson, C.J., \& Cronin, J.J. (2001). Managing Behavioral Intentions in Diverse Cultural Environments: An Investigation of Service Quality, Service Value, and Satisfaction for American and Ecuadorian Fast-Food Customers. Journal of international management, 7, no. 2: 129-149. https://dx.doi.org/10.1016/S1075-4253(00)00041-7.

Cao, Y., Lu, Y., Gupta, S., \& Yang, S. (2014). The Effects of Differences between E-Commerce and M-Commerce on the Consumers' Usage Transfer from Online to Mobile Channel. International journal of mobile communications, 13, no. 1: 51-70. https://dx.doi.org/10.1504/IJMC.2015.065890.

Cassel, C., Hackl, P., \& Westlund, A.H. (1999). Robustness of Partial Least-Squares Method for Estimating Latent Variable Quality Structures. Journal of applied statistics, 26, no. 4: 435-446. https://dx.doi.org/10.1080/02664769922322.

Chang, H.H., Wang, Y.H., \& Yang, W.Y. (2009). The Impact of E-Service Quality, Customer Satisfaction and Loyalty on E-Marketing: Moderating Effect of Perceived Value. Total quality management \& business excellence, 20, no. 4: 423-443. https://dx.doi.org/10.1080/14783360902781923.

Chen, S.C., \& Lin, C.-P. (2019). Understanding the Effect of Social Media Marketing Activities: The Mediation of Social Identification, Perceived Value, and Satisfaction. Technological $\begin{array}{llll}\text { forecasting and } \quad \text { social } & \text { 22-32. }\end{array}$ https://dx.doi.org/10.1016/J.TECHFORE.2018.11.025.

Cohen, J. (1988). Statistical Power Analysis for the Behavioral Sciences. Hillsdle. 2 ed. New Jersey: Lawrence Erlbaum Associates. 
Cohen, L., Manion, L., \& Morrison, K. (2018). Research Methods in Education. 8 ed. New York: Routledge.

Coyle, J.R., \& Thorson, E. (2001). The Effects of Progressive Levels of Interactivity and Vividness in Web Marketing Sites. Journal of advertising, 30, no. 3: 65-77. https://dx.doi.org/10.1080/00913367.2001.10673646.

Cronin, J.J., Brady, M.K., \& Hult, G.T.M. (2000). Assessing the Effects of Quality, Value, and Customer Satisfaction on Consumer Behavioral Intentions in Service Environments. Journal of retailing, 76, no. 2: 193-218. https://dx.doi.org/10.1016/S0022-4359(00)00028-2.

Dijkstra, T.K., \& Henseler, J. (2015). Consistent Partial Least Squares Path Modeling. Management information systems quarterly, 39, no. 2: 297-316. https://dx.doi.org/10.25300/MISQ/2015/39.2.02.

Dodds, W.B., Monroe, K.B., \& Grewal, D. (1991). Effects of Price, Brand, and Store Information on Buyers' Product Evaluations. Journal of marketing research, 28, no. 3: 307-319. https://dx.doi.org/10.2307/3172866.

Edward, M., \& Sunil, S. (2011). Role of Switching Costs in the Service Quality, Perceived Value, Customer Satisfaction and Customer Retention Linkage. Asia pacific journal of marketing and logistics, 23, no. 3: 327-345. https://dx.doi.org/10.1108/13555851111143240.

Eroglu, S.A., Machleit, K.A., \& Davis, L.M. (2003). Empirical Testing of a Model of Online Store Atmospherics and Shopper Responses. Psychology \& marketing, 20, no. 2: 139-150. https://dx.doi.org/10.1002/MAR.10064.

Evans, J.R., \& King, V.E. (1999). Business-to-Business Marketing and the World Wide Web: Planning, Managing, and Assessing Web Sites. Industrial marketing management, 28, no. 4: 343-358. https://dx.doi.org/10.1016/S0019-8501(98)00013-3.

Gan, C., \& Wang, W. (2017). The Influence of Perceived Value on Purchase Intention in Social Commerce Context. Internet research, 27, no. 4: 772-785. https://dx.doi.org/10.1108/INTR06-2016-0164.

Gefen, D., Rigdon, E.E., \& Straub, D. (2011). An Update and Extension to Sem Guidelines for Admnistrative and Social Science Research. Management information systems quarterly, 35, no. 2.

Geisser, S. (1974). A Predictive Approach to the Random Effect Model. Biometrika, 61, no. 1: 101107. https://dx.doi.org/10.1093/BIOMET/61.1.101.

Grewal, D., Monroe, K.B., \& Krishnan, R. (1998). The Effects of Price-Comparison Advertising on Buyers' Perceptions of Acquisition Value, Transaction Value, and Behavioral Intentions. Journal of marketing, 62, no. 2: 46-59.

Haigh, R. (1993). The Ageing Process: A Challenge for Design. Applied ergonomics, 24, no. 1: 9-14. https://dx.doi.org/10.1016/0003-6870(93)90153-Z.

Hair, J.F., Black, W.C., Babin, B.J., \& Anderson, R.E. (2014). Multivariate Data Analysis. 7 ed. Harlow: Pearson Education Limited.

Hair, J.F., Celsi, M., Ortinau, D.J., \& Bush, R.P. (2017a). Essentials of Marketing Research. 4 ed. New York: McGraw-Hill.

Hair, J.F., Hult, G.T.M., Ringle, C.M., \& Sarstedt, M. (2017b). A Primer on Partial Least Squares Structural Equation Modelling (Pls-Sem). London: SAGE Publications.

Harris, L.C., \& Goode, M.M.H. (2010). Online Servicescapes, Trust, and Purchase Intentions. Journal of services marketing, 24, no. 3: 230-243. https://dx.doi.org/10.1108/08876041011040631.

Hoffman, D.L., \& Novak, T.P. (1996). Marketing in Hypermedia Computer-Mediated Environments: Conceptual Foundations. Journal of marketing, 60, no. 3: 50-68. https://dx.doi.org/10.2307/1251841. 
Hoque, A.Y., \& Lohse, G.L. (1999). An Information Search Cost Perspective for Designing Interfaces for Electronic Commerce. Journal of marketing research, 36, no. 3: 387-394. https://dx.doi.org/10.1177/002224379903600307.

Hsu, C.-L., \& Lin, J.C.-C. (2016). Effect of Perceived Value and Social Influences on Mobile App Stickiness and in-App Purchase Intention. Technological forecasting and social change, 108: 42-53. https://dx.doi.org/10.1016/J.TECHFORE.2016.04.012.

Hsu, C.-L., \& Lin, J.C.-C. (2015). What Drives Purchase Intention for Paid Mobile Apps? - an Expectation Confirmation Model with Perceived Value. Electronic commerce research and applications, 14, no. 1: 46-57. https://dx.doi.org/10.1016/J.ELERAP.2014.11.003.

Hu, H.H., \& Kandampully, J. (2009). Relationships and Impacts of Service Quality, Perceived Value, Customer Satisfaction, and Image: An Empirical Study. Service industries journal, 29, no. 2: 111-125. https://dx.doi.org/10.1080/02642060802292932.

lacobucci, D., Saldanha, N., \& Deng, X. (2007). A Meditation on Mediation: Evidence That Structural Equations Models Perform Better Than Regressions. Journal of consumer psychology, 17, no. 2: 139-153. https://dx.doi.org/10.1016/S1057-7408(07)70020-7.

Janda, S., Trocchia, P.J., \& Gwinner, K.P. (2002). Consumer Perceptions of Internet Retail Service Quality. International journal of service industry management, 13, no. 5: 412-431. https://dx.doi.org/10.1108/09564230210447913.

Kanji, G.K. (2002). Business Excellence: Make It Happen. Total quality management \& business excellence, 13, no. 8: 1115-1124. https://dx.doi.org/10.1080/09544120200000007.

Karson, E.J., \& Fisher, R.J. (2005). Reexamining and Extending the Dual Mediation Hypothesis in an on-Line Advertising Context. Psychology \& marketing, 22, no. 4: 333-351. https://dx.doi.org/10.1002/MAR.20062.

Kim, H.-W., Chan, H.C., Gupta, S. (2007). Value-Based Adoption of Mobile Internet: An Empirical Investigation. Decision Support Systems, 43: 111-126. https://dx.doi.org/10.1016/J.DSS.2005.05.009.

Ko, E., Kim, E.Y., \& Lee, E.K. (2009). Modeling Consumer Adoption of Mobile Shopping for Fashion Products in Korea. Psychology \& marketing, 26, no. 7: 669-687. https://dx.doi.org/10.1002/MAR.20294.

Koupai, M.R., Alipourdarvish, Z., \& Sardar, S. (2015). Effects of Trust and Perceived Value on Customer Loyalty by Mediating Role of Customer Satisfaction and Mediating Role of Customer Habit (Case Study: Agricultural Internet Bank Customers in Tehran). Advanced Social Humanities Management, 2, no. 1: 102-112.

Kuo, Y.-F., Wu, C.-M., \& Deng, W.-J. (2009). The Relationships among Service Quality, Perceived Value, Customer Satisfaction, and Post-Purchase Intention in Mobile Value-Added Services. Computers in human behavior, 25, no. 4: 887-896. https://dx.doi.org/10.1016/J.CHB.2009.03.003.

Lai, T.L. (2004). Service Quality and Perceived Value's Impact on Satisfaction, Intention and Usage of Short Message Service (Sms). Information systems frontiers, 6, no. 4: 353-368. https://dx.doi.org/10.1023/B:ISFI.0000046377.32617.3D.

Lee, Y.-K., Park, K.-H., Park, D.-H., Lee, K.A., \& Kwon, Y.-J. (2005). The Relative Impact of Service Quality on Service Value, Customer Satisfaction, and Customer Loyalty in Korean Family Restaurant Context. International journal of hospitality \& tourism administration, 6, no. 1 : 27-51. https://dx.doi.org/10.1300/J149V06N01_03.

Li, G., Li, G., \& Kambele, Z. (2012). Luxury Fashion Brand Consumers in China: Perceived Value, Fashion Lifestyle, and Willingness to Pay. Journal of business research, 65, no. 10: 15161522. https://dx.doi.org/10.1016/J.JBUSRES.2011.10.019. 
Lien, C.H., Wen, M.-J., \& Wu, C.C. (2011). Investigating the Relationships among E-Service Quality, Perceived Value, Satisfaction, and Behavioral Intentions in Taiwanese Online Shopping. Asia pacific management review, 16, no. 3: 211-223. https://dx.doi.org/10.6126/APMR.2011.16.3.01.

Lin, H.-H., \& Wang, Y.-S. (2006). An Examination of the Determinants of Customer Loyalty in Mobile Commerce Contexts. Information \& management, 43, no. 3: 271-282. https://dx.doi.org/10.1016/J.IM.2005.08.001.

Liu, Y., \& Shrum, L.J. (2002). What Is Interactivity and Is It Always Such a Good Thing? Implications of Definition, Person, and Situation for the Influence of Interactivity on Advertising Effectiveness. Journal of advertising, 31, no. 4: 53-64. https://dx.doi.org/10.1080/00913367.2002.10673685.

Lu, H.-P., \& Su, P.Y.-H. (2009). Factors Affecting Purchase Intention on Mobile Shopping Web Sites. Internet research, 19, no. 4: 442-458. https://dx.doi.org/10.1108/10662240910981399.

Malhotra, N.K., \& Dash, S. (2016). Marketing Research: An Applied Orientation. Pearson.

Menon, S., \& Kahn, B.E. (2002). Cross-Category Effects of Induced Arousal and Pleasure on the Internet Shopping Experience. Journal of retailing, 78, no. 1: 31-40. https://dx.doi.org/10.1016/S0022-4359(01)00064-1.

Nilsson, E., \& Ballantyne, D. (2014). Reexamining the Place of Servicescape in Marketing: A ServiceDominant Logic Perspective. Journal of services marketing, 28, no. 5: 374-379. https://dx.doi.org/10.1108/JSM-01-2013-0004.

Oliver, R.L. (1993). Cognitive, Affective, and Attribute Bases of the Satisfaction Response. Journal of consumer research, 20, no. 3: 418-430. https://dx.doi.org/10.1086/209358.

Papadopoulou, P., Andreou, A., Kanellis, P., \& Martakos, D. (2001). Trust and Relationship Building in Electronic Commerce. Internet research, 11, no. 4: 322-332. https://dx.doi.org/10.1108/10662240110402777.

Parasuraman, A., \& Grewal, D. (2000). The Impact of Technology on the Quality-Value-Loyalty Chain: A Research Agenda. Journal of the academy of marketing science, 28, no. 1: 168-174. https://dx.doi.org/10.1177/0092070300281015.

Patterson, P.G., \& Spreng, R.A. (1997). Modelling the Relationship between Perceived Value, Satisfaction and Repurchase Intentions in a Business-to-Business, Services Context: An Empirical Examination. International journal of service industry management, 8, no. 5: 414434. https://dx.doi.org/10.1108/09564239710189835.

Preacher, K.J., \& Hayes, A.F. (2008). Asymptotic and Resampling Strategies for Assessing and Comparing Indirect Effects in Multiple Mediator Models. Behavior research methods, 40, no. 3: 879-891. https://dx.doi.org/10.3758/BRM.40.3.879.

Ramayah, T., Cheah, J.H., Chuah, F., Ting, H., \& Memon, M. (2018). Partial Least Squares Structural Equation Modelling (Pls-Sem) Using Smartpls 3.0: An Updated and Practical Guide to Statistical Analysis. 2 ed. Kuala Lumpur: Pearson Malaysia Sdn. Bhd.

Sicilia, M., Ruiz, S., \& Munuera, J.L. (2005). Effects of Interactivity in a Web Site: The Moderating Effect of Need for Cognition. Journal of advertising, 34, no. 3: 31-44. https://dx.doi.org/10.1080/00913367.2005.10639202.

Statista (2018). Mobile E-Commerce Is up and Poised for Further Growth. Accessed 29 May, 2020. Form of Item. https://www.statista.com/chart/13139/estimated-worldwide-mobile-ecommerce-sales/.

Stone, M. (1974). Cross-Validation and Multinomial Prediction. Biometrika, 61, no. 3: 509-515. https://dx.doi.org/10.1093/BIOMET/61.3.509. 
Sundar, S.S., \& Kim, J. (2005). Interactivity and Persuasion. Journal of interactive advertising, 5, no. 2: 5-18. https://dx.doi.org/10.1080/15252019.2005.10722097.

Szymanski, D.M., \& Hise, R.T. (2000). E-Satisfaction: An Initial Examination. Journal of retailing, 76, no. 3: 309-322. https://dx.doi.org/10.1016/S0022-4359(00)00035-X.

Tam, J.L.M. (2004). Customer Satisfaction, Service Quality and Perceived Value: An Integrative Model. Journal of marketing management, 20, no. 7: 897-917. https://dx.doi.org/10.1362/0267257041838719.

Tankovic, A.C., \& Benazic, D. (2018). The Perception of E-Servicescape and Its Influence on Perceived E-Shopping Value and Customer Loyalty. Online information review, 42, no. 7: 1124-1145. https://dx.doi.org/10.1108/OIR-12-2016-0354.

Thaler, R. (1985). Mental Accounting and Consumer Choice. Marketing science. https://dx.doi.org/10.1287/MKSC.4.3.199.

Tran, G.A., \& Strutton, D. (2016). Investigating E-Servicescape, Trust, E-Wom, and Customer Loyalty. In Celebrating America's Pastimes: Baseball, Hot Dogs, Apple Pie and Marketing?, 77-81: Springer.

Voss, C., Roth, A.V., \& Chase, R.B. (2008). Experience, Service Operations Strategy, and Services as Destinations: Foundations and Exploratory Investigation. Production and operations management, 17, no. 3: 247-266. https://dx.doi.org/10.3401/POMS.1080.0030.

Wang, Z. (2020). A study on foreign tourists' purchasing behaviour. Journal of Business \& Finance in Emerging Markets, 3, no.1:45-54. https://doi.org/10.32770/jbfem.vol345-54

Wu, J.-H., \& Wang, S.-C. (2005). What Drives Mobile Commerce? An Empirical Evaluation of the Revised Technology Acceptance Model. Information \& management, 42, no. 5: 719-729. https://dx.doi.org/10.1016/J.IM.2004.07.001.

Wu, W.-Y., Lee, C.-L., Fu, C.-S., \& Wang, H.-C. (2013). How Can Online Store Layout Design and Atmosphere Influence Consumer Shopping Intention on a Website. International journal of retail \& distribution management, 42, no. 1: 4-24. https://dx.doi.org/10.1108/IJRDM-012013-0035.

Yang, Z., \& Peterson, R.T. (2004). Customer Perceived Value, Satisfaction, and Loyalty: The Role of Switching Costs. Psychology \& marketing, 21, no. 10: 799-822. https://dx.doi.org/10.1002/MAR.20030.

Yoon, E. (2012). Effects of Website Environmental Cues on Consumers' Response and Outcome Behaviors. Public Access Theses and Dissertations, College of Education and Human Science.

Zeithaml, V.A. (1988). Consumer Perceptions of Price, Quality, and Value: A Means-End Model and Synthesis of Evidence. Journal of marketing, 52, no. 3: 2-22. https://dx.doi.org/10.2307/1251446.

Zeithaml, V.A., Berry, L.L., \& Parasuraman, A. (1996). The Behavioral Consequences of Service Quality. Journal of marketing, 60, no. 2: 31-46. https://dx.doi.org/10.2307/1251929.

Zhang, H., Lu, Y., Gupta, S., \& Gao, P. (2015). Understanding Group-Buying Websites Continuance: An Extension of Expectation Confirmation Model. Internet research, 25, no. 5: 767-793. https://dx.doi.org/10.1108/INTR-05-2014-0127. 